\title{
Genetic diversity in curtoviruses: a highly divergent strain of Beet mild curly top virus associated with an outbreak of curly top disease in pepper in Mexico
}

\author{
L.-F. Chen $\cdot$ E. Vivoda $\cdot$ R. L. Gilbertson
}

Received: 12 October 2010/Accepted: 3 December 2010/Published online: 31 December 2010

(C) The Author(s) 2010. This article is published with open access at Springerlink.com

\begin{abstract}
A full-length curtovirus genome was PCRamplified and cloned from peppers in Mexico with symptoms of curly top disease. The cloned DNA of this isolate, MX-P24, replicated in Nicotiana tabacum protoplasts and was infectious in $N$. benthamiana plants. Sequence analysis revealed that the MX-P24 isolate had a typical curtovirus genome organization and was most similar to beet mild curly top virus (BMCTV). However, sequence identities were at the threshold value for establishment of a new curtovirus species. To further investigate the biological properties of MX-P24, an agroinoculation system was generated. Agroinoculated shepherd's purse plants developed typical curly top symptoms, and virus from these plants was transmissible by the beet leafhopper (Circulifer tenellus). The host range of MX-P24 was similar to that of BMCTV, with curly top symptoms induced in common bean, pepper, pumpkin, shepherd's purse and tomato plants and mild or no symptoms induced in sugar beet plants. Together, these results indicate that MX-P24 is a highly divergent strain of BMCTV associated with an outbreak of curly top disease in peppers in Mexico.
\end{abstract}

Nucleotide sequence data are available in the GenBank database under accession number HQ214016.

L.-F. Chen · R. L. Gilbertson ( $₫)$

Department of Plant Pathology,

University of California Davis,

Davis, CA 95616, USA

e-mail: rlgilbertson@ucdavis.edu

E. Vivoda

Harris Moran Seed Company,

9241 Mace Blvd, Davis, CA 95618, USA

\section{Introduction}

Curly top disease is caused by viruses in the genus Curtovirus (family Geminiviridae). The disease affects over 300 plant species, including crops, ornamentals and weeds from at least 44 families [3]. Curtoviruses have a monopartite genome ( $\sim 2.9$ kilobases), infect dicotyledonous hosts and are transmitted by the beet leafhopper (Circulifer tenellus Baker). Since the early 1900s, curly top has been an economically important disease in the western United States (e.g., California, Idaho, New Mexico, Utah and Washington). The major crops impacted include common bean, pepper, spinach, sugar beet, and tomato [3]. The symptoms of curly top include stunted and distorted plant growth; leaf curling, crumpling, yellowing, vein swelling and distortion; and necrosis and hyperplasia of the phloem $[3,16]$. Although most reports of curly top have come from the United States, curly-top-like symptoms also have been reported from Mexico and South America [3, 42], as well as in the Old World (e.g., Iran [3, 6, 18]).

Analyses of curtovirus genome sequences and biological properties (host range and symptom severity) have revealed at least seven distinct curtovirus species. Species from the New World include Beet curly top virus (BCTV, the type strain and previously the Cal/Logan strain of BCTV), Beet mild curly top virus (BMCTV, previously the Worland strain of BCTV), Beet severe curly top virus (BSCTV, previously the CFH strain of BCTV) [8, 31, 35-38], Horseradish curly top virus (HrCTV) [23], Pepper yellow dwarf virus (PeYDV) [24] and Spinach curly top virus (SCTV) [1]. Beet curly top Iran virus (BCTIV) and BSCTV have been described from the Old World [6, 18]. Relatively little is known about the level of variability among isolates of curtovirus species. Several studies have suggested that genetic diversity exists among isolates, and 
that it may be dependent on the curtovirus species, host plant and geographic location. For example, based on restriction enzyme digestion analyses of full-length clones of field isolates from the western United States, Stenger and McMahon [39] found a number of minor genotypic variants of BMCTV (Worland strain of BCTV) and BSCTV (CFH strain of BCTV) as well as two BMCTV genotypes that were more divergent and were considered strains. More recently, a high level of genetic diversity was reported among BCTV isolates infecting sugar beet in the western United States [41]. In contrast, results of a number of studies have indicated that isolates of BSCTV, including those from Old World (e.g., Iran [18]) and New World (e.g., western United States [11, 12, $39,41])$ locations, showed a low level of genetic diversity.

The curtovirus genome organization is conserved, with seven open reading frames (ORFs) transcribed in a bidirectional fashion [19, 31, 35, 38] from an $\sim 450$-bp intergenic region (IR) that contains the origin of viral DNA replication [40]. The three virion-sense ORFs, V1, V2 and V3, encode the capsid protein (CP), a singlestranded (ss)/double-stranded (ds) DNA regulator and a putative movement protein (MP), respectively [5, 19]; these genes are highly conserved among curtoviruses [8]. The four complementary-sense ORFs, C1, C2, C3 and C4, encode the replication-associated protein (Rep), a pathogenicity-associated protein involved in a recovery phenotype, a replication enhancer protein and a protein affecting cell division and symptom development, respectively $[2,20,25,32,34,43]$; these genes are more divergent [8].

Curly top can be an economically important disease of pepper, especially when plants are infected early and become severely stunted, chlorotic and produce little marketable fruit. For example, in 2001 and 2003, curly top caused losses of $20-50 \%$ to chile pepper production in southwestern New Mexico, U.S.A. [12]. Beginning in 2005, outbreaks of curly top-like symptoms (stunted growth and upward curling and yellowing of leaves) have been reported in pepper fields in central Mexico [42]. Curtovirus infection in these plants was confirmed by polymerase chain reaction (PCR) with general curtovirus primers, and analyses of sequences of PCR-amplified fragments suggested that BMCTV was involved [this study and 42]. Here, we report the complete sequence of an infectious clone of a curtovirus isolate associated with this disease outbreak, as well as the completion of Koch's postulates by showing that this isolate induces curly top symptoms in pepper. We further show that this isolate is most similar to BMCTV based upon sequence analysis, host range, and symptomatology; however, the sequences of this and other BMCTV isolates from Mexico are $>10 \%$ divergent from known BMCTV isolates, revealing a high level of genetic diversity within this curtovirus species.

\section{Materials and methods}

\section{Collection of samples}

Samples of peppers with curly-top-like disease symptoms were collected in fields in the Zacatecas state of Mexico in 2007. Disease symptoms included stunted growth and leaves with upward curling, crumpling and interveinal chlorosis.

\section{DNA extraction and polymerase chain reaction}

Total genomic DNA was extracted from leaf tissues by the Dellaporta method [13]. DNA extracts were used in the PCR with the general curtovirus primer pair (BGv377 and BGc1509), which directs the amplification of an $\sim 1.1-\mathrm{kb}$ fragment from a conserved region of the curtovirus genome [7]. Primer pair BMCTVv2195 and BMCTVc514 [11] also was used in the PCR to direct the amplification of an $\sim 1.2$-kb fragment, which includes the more divergent IR and $\mathrm{C} 1 / \mathrm{C} 4 \mathrm{ORF}$ sequences. The PCR parameters were as described previously $[8,11]$. PCR-amplified DNA fragments were cloned using the TA cloning system (Invitrogen, Carlsbad, CA, USA), and sequenced [10].

\section{Construction and characterization of an infectious clone}

Overlapping primers MXv2464 (5'-ACCTCCTGCAGCAG CATCATTAGC-3') and MXc2470 (5'-AGGCTACTG CAGAGGCATTAAATGCA- $3^{\prime}$ ) with a $P$ stI site (shown in italics), were designed based upon sequences of curtovirus DNA fragments that were PCR-amplified from symptomatic pepper tissues. These overlapping primers were used in the PCR with proofreading DNA polymerase (Platinum Taq DNA polymerase High Fidelity, Invitrogen) to direct amplification of the genomic DNA of this curtovirus isolate. PCR-amplified DNA fragments of the expected size $(\sim 3.0 \mathrm{~kb})$ were cloned using the pZero-Blunt cloning system (Invitrogen), and a recombinant plasmid (pMX-P24-1.0) with an $\sim 3.0-\mathrm{kb}$ insert was identified by restriction digestion analysis and then sequenced.

DNA sequences were analyzed and assembled with Vector NTI software (Version 10; Invitrogen). The BLAST program (National Center for Biotechnology Information) was used to compare sequences available in GenBank. Sequence alignments were generated with the optimal alignment method of Vector NTI software. 
Generation of a multimeric MX-P24 clone and assessment of replication competence and infectivity

A 1.9-mer construct of the putative full-length curtovirus clone in pMX-P24-1.0 was generated by digesting the plasmid with $X b a \mathrm{I}$ and $P s t \mathrm{I}$ and gel-purifying the resulting $\sim 2.7-\mathrm{kb}$ fragment. This fragment was cloned into XbaI/ PstI-digested pBluescript II KS+ to generate pMX-P24-0.9. The full-length fragment, excised from pMX-P24-1.0 with PstI, was then cloned into PstI-digested pMX-P24-0.9 to generate pMX-P24-1.9.

Replication competence was determined by transfecting $N$. tabacum cv. Xanthi protoplasts with pMX-P24-1.9 as described previously [21]. Southern blot hybridization analysis with a BMCTV-[W4] probe was used to detect newly replicated viral DNA forms in DNA extracts prepared from transfected protoplasts at 0,3 and 6 days post-electroporation (dpe). Infectivity was determined by particle bombardment inoculation of $N$. benthamiana seedlings at the three- to five-leaf stage with pMX-P24-1.9 DNA. Inoculated plants were maintained in a growth chamber kept at $25^{\circ} \mathrm{C}$ and observed for symptoms at 10 and 14 days post-bombardment (dpb). The presence of viral DNA in selected plants was determined by PCR with the general curtovirus primer pair.

\section{Development of an agroinoculation system}

The multimeric insert (1.9-mer) was excised from pMXP24-1.9 with PvuII and cloned into the binary vector pVCCBin19, digested with SmaI, to generate pVCCBin19MX-P24-1.9. Agrobacterium tumefaciens (strain EHA105) was transformed with pVCCBin19-MX-P24-1.9 by electroporation. Transformants having the expected-size recombinant plasmid were identified by restriction enzyme digestion. To assess infectivity, one transformant was grown in liquid Luria-Bertani medium for two days and used to inoculate $N$. benthamiana and shepherd's purse (Capsella bursapastoris) plants by needle puncture inoculation [21].

Leafhopper colonies and transmission assays

A colony of nonviruliferous beet leafhoppers was maintained in a growth chamber as described previously [29]. Insects used in virus transmission experiments were given a minimum $48 \mathrm{~h}$ acquisition access period (AAP) on infected shepherd's purse plants and are referred to as viruliferous leafhoppers. For plant inoculations, groups of six to eight adult viruliferous leafhoppers were put into small clip-on leaf cages, which were placed onto leaves of seedlings for a 48-h inoculation access period (IAP) as described previously [9].
Host range assays

To determine the host range of the MX-P24 isolate, agroinoculation and leafhopper transmission experiments were conducted with selected plant species. N. benthamiana, common bean (Phaseolus vulgaris cv. Topcrop), pepper (Capsicum annum cv. Golden California Wonder), pumpkin (Cucurbita pepo cv. Small sugar), tomato (Solanum lycopersicum cv. Glamour), shepherd's purse and sugar beet (Beta vulgaris L., lineR289) seedlings were agroinoculated or exposed to viruliferous leafhoppers as described above. Inoculated plants were maintained in a growth chamber at $25^{\circ} \mathrm{C}$ for 30 days. Plants were visually examined for development of disease symptoms, and selected plants were tested for infection by PCR with the general curtovirus primer pair or curtovirus species-specific primer pairs [11].

Generation of MX-P24-specific primers

A virion-sense primer, specific for MX-P24, was designed by aligning curtovirus genome sequences and identifying divergent regions. This primer was paired with the general curtovirus complementary-sense primer (BGc1509) for the PCR. The PCR parameters were the same as those described previously [11], and the specificity of the primer pair was assessed in PCR assays with DNA extracts prepared from plants infected with BCTV-[US:Log:76], BMCTV-[US:Wor4] and BSCTV-[US:Cfh].

\section{Results}

Detection of curtovirus DNA in symptomatic pepper plants from Mexico

The expected-size $\sim 1.1$ - and 1.2-kb fragments were consistently amplified from DNA extracts prepared from pepper leaves with curly top-like symptoms collected in Mexico in 2007 with the general curtovirus and BMCTVv2195/BMCTVc514 primer pairs, respectively. Sequence analysis confirmed that these were curtovirus DNA fragments. Furthermore, partial V2 and CP ORF sequences were $90-93 \%$ identical to those of BMCTV, BSCTV and BCTV isolates, whereas partial C1 and C4 ORF sequences were 92 and 94\%, 74 and 67\%, and 46 and $65 \%$ identical, respectively. The IR sequence was $71 \%$, $57 \%$ and $46 \%$ identical to those of BMCTV, BSCTV and BCTV, respectively. These results are consistent with the involvement of a curtovirus in these disease outbreaks, but they do not reveal the precise nature of this curtovirus isolate (i.e., whether it is an isolate of a previously characterized curtovirus species or of a distinct species). 
Analysis of the complete nucleotide sequence of a curtovirus isolate associated with curly top disease of peppers in Mexico

The complete genome of an isolate associated with diseased pepper samples (referred to as MX-P24) was amplified by PCR with overlapping primers [27], and the resulting $\sim 3.0-\mathrm{kb}$ fragment was cloned to generate $\mathrm{pMX}$ P24-1.0. Analysis of the complete sequence of the MX-P24 isolate revealed that it is 2963 nucleotides long (GenBank accession number HQ214016) and has a typical curtovirus genome organization (i.e., seven ORFs corresponding to $\mathrm{V} 1, \mathrm{~V} 2, \mathrm{~V} 3, \mathrm{C} 1, \mathrm{C} 2, \mathrm{C} 3$ and $\mathrm{C} 4)$. The results of comparisons of the nucleotide and amino acid sequences of MX-P24 with those of other curtoviruses are shown in Table 1. The complete nucleotide sequence of MX-P24 was nearly identical (97-98\%) to the complete sequences of other curtovirus isolates from Mexico recently deposited in GenBank. The MX-P24 IR had a high degree of identity with those of the other curtovirus isolates from Mexico, although it is worth noting that there was divergence in the IR sequences of these isolates. The highest level of diversity was in the right IR (RIR, the sequence between the stem-loop and the start codon of V3 ORF) and with isolate BMCTV-[MX-05] (Table 1).

In terms of previously described curtovirus species, the MX-P24 sequence had the highest overall identities with BMCTV-[US:Wor4] (88.9\%) and BMCTV-[US:Wor] (88.8\%), followed by PeYDV (83.7\%) and BSCTV[US:Cfh] (79.6\%). The MX-P24 IR sequence was highly divergent $(\leq 71.6 \%$ identity), especially in the RIR.
However, the MX-P24 Rep protein high-affinity binding sites (GGGGG and GGGAG) were similar to those of BMCTV isolates (GGGTG and GGGAG).

Results of comparisons of individual nucleotide and amino acid sequences of MX-P24 ORFs with those of other curtovirus isolates were similar to those obtained for the complete sequences, i.e., MX-P24 was most similar to BMCTV, but the sequences were relatively divergent (88.3-95\% identity). Furthermore, these comparisons did not reveal evidence of recombination, nor did an analysis of the MX-P24 sequence with the RDP program [26, data not shown]. These results suggest that the MX-P24 isolate (and the other isolates from Mexico) are most closely related to BMCTV. However, because the overall sequence identity $(88.9 \%)$ is slightly below the $89 \%$ threshold recommended for establishment of new curtovirus species [17], it is not clear whether MX-P24 is a highly divergent isolate of BMCTV or a new curtovirus that has evolved from a BMCTV progenitor.

Development of an infectious clone and determination of host range and symptomatology

To define biological properties of MX-P24, a multimeric clone (pMX-P24-1.9) was generated for replication and infectivity studies. For replication studies, tobacco protoplasts were transfected with pMX-P24-1.9. Newly replicated viral DNA forms were detected in protoplasts at 3 and 6 dpe, whereas no such forms were detected in protoplasts electroporated with buffer alone (data not shown). Approximately $14 \mathrm{dpb}$ with pMX-P24-1.9, four of five

Table 1 Percent nucleotide and amino acid (in parentheses) identities for the whole genome (total), intergenic region and open reading frames of a curtovirus isolate from Mexico (MX-P24) and isolates of Beet mild curly top virus (BMCTV) and other curtovirus species (Beet

curly top virus [BCTV], Beet severe curly top virus [BSCTV], Horseradish curly top virus [HrCTV], Pepper yellow dwarf virus [PeYDV] and Spinach curly top virus [SCTV])

\begin{tabular}{|c|c|c|c|c|c|c|c|c|c|c|c|}
\hline \multirow[t]{2}{*}{ Curtovirus $^{\mathrm{a}}$} & \multirow[t]{2}{*}{ Total } & \multicolumn{3}{|c|}{ Intergenic region } & \multicolumn{7}{|c|}{ Open reading frames } \\
\hline & & IR & LIR & RIR & V3 & $\mathrm{V} 2$ & V1 & $\mathrm{C} 3$ & $\mathrm{C} 2$ & $\mathrm{C} 1$ & $\mathrm{C} 4$ \\
\hline BMCTV-[MX:SLP2] & 97.9 & 94.5 & 100 & 92.7 & $99.6(98.9)$ & 99.5 (97.6) & $99.5(99.2)$ & $99.5(98.5)$ & 99.3 (98.6) & $98.0(98.1)$ & $98.4(96.5$ \\
\hline BMCTV-[MX:05] & 96.7 & 88.3 & 96.8 & 85.5 & $98.2(93.6)$ & $97.9(93.7)$ & $98.2(97.3)$ & $97.6(94.9)$ & $97.5(95.9)$ & $98.1(98.1)$ & $99.2(97.7)$ \\
\hline BMCTV-[US:Wor4] & 88.9 & 70.6 & 86.3 & 65.7 & $88.3(87.2)$ & $91.9(89.0)$ & $91.5(95.7)$ & $89.1(86.1)$ & $92.1(82.4)$ & $92.9(93.9)$ & $94.2(84.9)$ \\
\hline BMCTV-[US:Wor] & 88.8 & 71.6 & 85.3 & 67.0 & $89.4(87.2)$ & $92.9(89.8)$ & $91.9(95.7)$ & $89.1(86.1)$ & $91.4(81.1)$ & $92.7(93.0)$ & $95.0(87.2)$ \\
\hline PeYDV & 83.7 & 63.1 & 81.1 & 58.6 & $89.0(89.4)$ & $92.9(92.1)$ & $88.0(96.1)$ & $83.2(85.4)$ & $84.9(77.0)$ & $86.8(93.6)$ & $88.4(82.6)$ \\
\hline BSCTV-[US:Cfh] & 79.6 & 56.9 & 63.5 & 54.4 & $87.9(83)$ & $92.4(87.4)$ & $91.2(94.1)$ & $72.7(67.2)$ & $60.4(47.0)$ & $76.0(76.7)$ & $67.4(46.6)$ \\
\hline BCTV-[US:Log:76] & 75.3 & 46.1 & 11.6 & 55.7 & 86.9 (81.9) & $91.3(84.3)$ & $90.8(94.1)$ & $70.1(65.7)$ & $56.6(40.3)$ & $71.5(65.7)$ & $65.1(38.4)$ \\
\hline SCTV & 75.5 & 47.7 & 23.2 & 55.2 & $82.6(81.9)$ & $76.0(73.2)$ & 80.1 (91.9) & $76.0(81.8)$ & $76.0(65.5)$ & $72.1(80.3)$ & $70.5(51.2$ \\
\hline HrCTV & 58.8 & 40.9 & 32.7 & 27.2 & $74.8(71.3)$ & $73.2(70.9)$ & $77.3(88.2)$ & $\mathrm{ND}^{\mathrm{b}}$ & $43.5(25.0)$ & $56.9(67.3)$ & 39.8 (16.5 \\
\hline
\end{tabular}

${ }^{a}$ Sequence comparisons included curtovirus sequences available in GenBank: BMCTV-[MX:SLP2] (EU586261), BMCTV-[MX:05] (EU193175), BMCTV-[US:Wor4] (AY134867), PeYDV (EU921828), BSCTV-[US:Cfh] (U02311), BCTV-[US:Log:76] (AF379637), SCTV (AY548948) and HrCTV (U49907)

${ }^{\mathrm{b}} \mathrm{ND}=$ not determined because HrCTV lacks the homologous gene 
$N$. benthamiana seedlings developed stunted growth and leaf downward curling and chlorosis (data not shown). The presence of curtovirus DNA in these symptomatic plants was confirmed by PCR with the general curtovirus primer pair. These results established that the MX-P24 clone is replication-competent and infectious.

An agroinoculation system was generated with the multimeric infectious MX-P24 clone, and agroinoculated $N$. benthamiana plants developed symptoms indistinguishable from those in plants infected via particle bombardment inoculation. Agroinoculated common bean and pumpkin plants developed typical curly top symptoms, including stunted growth and leaf crumpling, curling and yellowing (Table 2; Fig. 1). Severe symptoms also were induced in tomato, including severe upward leaf curling, pronounced interveinal chlorosis, vein purpling and necrosis. Shepherd's purse plants developed stunted growth, leaf curling and thickened and distorted stalks (Table 2; Fig. 1). Sugar beet and pepper plants agroinoculated with MX-P24 showed mild or no obvious symptoms; however, PCR analysis revealed symptomless infection in some of these plants (Table 2). In general, the host range and symptoms are similar to those of BMCTV; however, the symptom phenotype in tomato is different from that induced by BMCTV-[US: Wor4], which includes leaf curling distortion and vein purpling but little chlorosis.

To determine if MX-P24 is leafhopper-transmissible, beet leafhoppers were given a 48-h AAP on shepherd's purse plants infected with MX-P24 via agroinoculation. These viruliferous leafhoppers were then placed onto various plant species for a 48-h IAP. By $21 \mathrm{dpi}$, common bean, pumpkin, shepherd's purse and tomato plants exposed to viruliferous leafhoppers developed curly top symptoms similar to those observed in agroinoculated plants. Most of the sugar beet plants exposed to viruliferous leafhoppers developed no symptoms, although one developed mild upcurling and crumpling of leaves. Infection with MX-P24 was confirmed in the sugar beet plant with the mild symptoms, as well as in a number of symptomless plants (Table 2). In contrast to results obtained with agroinoculation, pepper plants exposed to viruliferous leafhoppers developed stunted growth, and leaves showed interveinal

Table 2 Host range and symptomatology of a curtovirus isolate (MX-P24) associated with an outbreak of curly top in peppers in Mexico

\begin{tabular}{|c|c|c|c|}
\hline Inoculation method & Host & Infectivity $^{\mathrm{a}}$ & Symptoms \\
\hline \multirow[t]{7}{*}{ Agroinoculation } & Beta vulgaris $\mathrm{L}$. & $13 / 21(4)$ & $\begin{array}{l}\text { No obvious symptoms or mild up-curling and chlorosis } \\
\text { of leaves }\end{array}$ \\
\hline & Capsella bursa-pastoris [L.] & $18 / 18(4)$ & $\begin{array}{l}\text { Stunted growth and distorted and twisted leaves and } \\
\text { stems }\end{array}$ \\
\hline & $\begin{array}{l}\text { Capsicum anпиит cv. Golden California } \\
\text { Wonder }\end{array}$ & $4 / 14(3)$ & No obvious symptoms \\
\hline & Cucurbita pepo cv. Small sugar & $7 / 11(3)$ & $\begin{array}{l}\text { Stunted growth and upward or downward curling, } \\
\text { crumpling and interveinal chlorosis of leaves }\end{array}$ \\
\hline & Nicotiana benthamiana & $65 / 66(17)$ & $\begin{array}{l}\text { Stunted growth and downward curling, crumpling, } \\
\text { yellowing and distortion of leaves }\end{array}$ \\
\hline & Phaseolus vulgaris cv. Topcrop & $11 / 24(4)$ & $\begin{array}{l}\text { Stunted growth and downward curling, crumpling and } \\
\text { yellowing of leaves }\end{array}$ \\
\hline & Solanum lycopersicum cv. Glamour & $15 / 24(4)$ & $\begin{array}{l}\text { Stunted and distorted growth and upward or downward } \\
\text { curling, yellowing and interveinal chlorosis of leaves }\end{array}$ \\
\hline \multirow[t]{7}{*}{$\begin{array}{l}\text { Leafhopper } \\
\text { transmission }\end{array}$} & B. vulgaris $\mathrm{L}$. & $7 / 12(3)$ & $\begin{array}{l}\text { No obvious symptoms or mild up-curling and chlorosis } \\
\text { of leaves }\end{array}$ \\
\hline & C. bursa-pastoris $[\mathrm{L}]$. & $15 / 15(4)$ & $\begin{array}{l}\text { Stunted growth and distorted and twisted leaves and } \\
\text { stems }\end{array}$ \\
\hline & C. аппиит cv. Golden California Wonder & $3 / 8(2)$ & $\begin{array}{l}\text { Stunted growth and upward curling, crumpling, } \\
\text { yellowing and interveinal chlorosis of leaves }\end{array}$ \\
\hline & C. pepo cv. Small Sugar & $7 / 12(3)$ & $\begin{array}{l}\text { Stunted growth and upward or downward curling, } \\
\text { crumpling and interveinal chlorosis of leaves }\end{array}$ \\
\hline & N. benthamiana & $\mathrm{ND}^{\mathrm{b}}$ & ND \\
\hline & P. vulgaris cv. Topcrop & $10 / 12(3)$ & $\begin{array}{l}\text { Stunted growth and downward curling, crumpling and } \\
\text { yellowing of leaves }\end{array}$ \\
\hline & S. lycopersicum cv. Glamour & $13 / 15(3)$ & $\begin{array}{l}\text { Stunted and distorted growth and upward or downward } \\
\text { curling, yellowing and interveinal chlorosis of leaves }\end{array}$ \\
\hline
\end{tabular}

\footnotetext{
${ }^{a}$ The number of plants infected/total inoculated is based on the development of disease symptoms or detection of curtovirus DNA in newly emerged leaves by PCR with general or MX-P24-specific primer pairs; the number in parentheses indicates the number of individual experiments

b Not determined because $N$. benthamiana is not a host for leafhopper feeding
} 

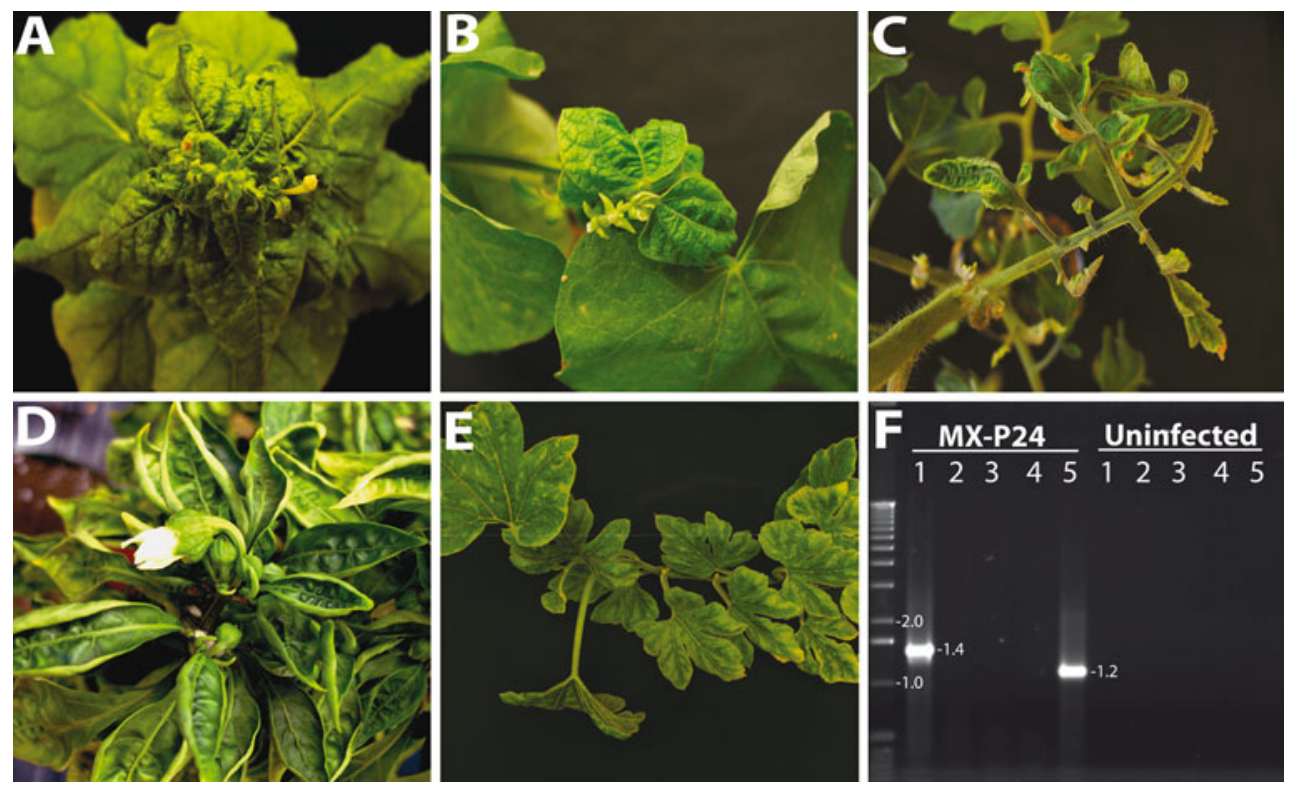

Fig. 1 Disease symptoms induced in selected plant species by a curtovirus isolate (MX-P24) associated with an outbreak of curly top in Mexico, and PCR detection of the virus with a specific primer pair. Symptoms in A, Nicotiana benthamiana; B, common bean (cv. Topcrop); C, tomato (cv. Glamour); D, pepper (cv. Golden California Wonder) and E, pumpkin (cv. Small Sugar) plants infected with MX-P24. F, Ethidium-bromide-stained gel showing DNA fragments amplified by PCR with curtovirus-specific primers individually paired with the general primer BGc1509 from DNA extracts prepared from MX-P24-infected and uninfected $N$. benthamiana plants. Lanes are as follows (primer names are shown in parentheses): 1, MX-P24 (MXv58); 2, BMCTV (BMCTVv2825); 3, BSCTV (BSCTVv2688); 4, BCTV (BCTVv2557) and 5, general curtovirus primer (BGv377) chlorosis, upward curling and crumpling (Table 2 and data not shown). PCR analysis confirmed MX-P24 infections in the symptomatic pepper plants.

\section{Development of an MX-P24-specific primer pair}

The curtovirus associated with the curly top virus outbreak in pepper in Mexico was not detected by PCR with previously developed curtovirus species-specific primers [11], including the BMCTV primer pair. Thus, a primer for specific detection of MX-P24 was developed by aligning the MX-P24 nucleotide sequences with those of other curtoviruses, including the other isolates from Mexico. A number of divergent regions were identified (data not shown), and a MX-P24-specific primer (v58:5'-CTGGCA CATGAAACTTATCGTGTAAG- ${ }^{\prime}$ ) was designed from the sequence of a divergent region in the IR. When paired with the general curtovirus primer $\mathrm{BGc1509}$, which anneals to a conserved region of the C2/C3 ORFs, the expected-size $\sim 1.4$-kb DNA fragment was PCR-amplified from DNA extracts prepared from leaves of MX-P24infected $N$. benthamiana plants (Fig.1F). No fragment was amplified from equivalent extracts prepared from uninfected plants or with species-specific primer pairs for BMCTV, BSCTV or BCTV (Fig.1F).

\section{Discussion}

Whitefly-transmitted geminiviruses (begomoviruses) are common in Mexico and cause diseases of considerable economic importance in cucurbits, peppers and tomatoes [28]. In contrast, there have been relatively few documented reports of diseases caused by curtoviruses in Mexico. This may reflect an absence of these viruses and/or the beet leafhopper vector, or a failure to detect curtovirus infections, perhaps due to the similarity of curly top symptoms to those induced by other viruses and prokaryotes (e.g., phytoplasma and Candidatus Liberibacter). Thus, documentation of curly top outbreaks in pepper fields in central Mexico (Zacatecas state) indicates that the disease can be economically important and raises questions about the distribution and importance of curtoviruses in Mexico.

To determine the nature of the curtovirus(es) associated with this curly top outbreak and to prove causality of disease (Koch's postulates), we characterized the MX-P24 isolate. Sequence analysis of an infectious clone revealed that MX-P24 has a typical curtovirus genome organization, and a high degree of identity with other isolates associated with this outbreak [42]. However, the relationship of these Mexican isolates with members of previously described 
curtovirus species was less clear. The MX-P24 isolate was most closely related to BMCTV, but sequence identities were slightly below the threshold value recommended by the ICTV for establishment of a distinct curtovirus species $[17,33]$. Furthermore, this sequence diversity was not attributed to recombination [1], as nucleotide differences were distributed throughout the genome. This divergence also explains why the BMCTV-specific primer [11] failed to detect MX-P24. Thus, on the basis of the sequence analysis alone, it was not clear whether the Mexican curtovirus isolates represent a divergent strain of BMCTV or a new curtovirus species.

The infectious clone of MX-P24 was used to investigate biological properties (host range and symptomatology) of this curtovirus isolate. The successful development of an MX-P24 agroinoculation system was significant, because our extensive efforts to develop such a system for BMCTV-[US:Wor4] have been unsuccessful [30, data not shown]. This may reflect true biological differences between these isolates or a technical issue, as an agroinoculation system was successfully developed for BMCTV-[US:Wor] [40]. However, the finding that the MX-P24 host range was similar to that of BMCTV (i.e., severe symptom phenotypes in common bean, $N$. benthamiana, pepper, pumpkin, shepherd's purse and tomato, and mild or no symptoms in sugar beet) is consistent with this isolate representing a strain of BMCTV.

The finding that peppers exposed to viruliferous leafhoppers carrying progeny virus derived from the infectious clone developed curly top symptoms (stunted growth and upward curling of leaves with crumpling and chlorosis) demonstrated causality of disease and established that the pepper disease in central Mexico is curly top. However, it was difficult to infect pepper with MX-P24, either by agroinoculation (symptomless infections only) or leafhopper transmission (low rates of symptomatic infection). The fact that agroinoculated peppers developed symptomless infections most likely reflects incompatibility between $A$. tumefaciens and this host. It is well known that the efficiency of plant transformation mediated by $A$. tumefaciens varies considerably among plant species [4] and that pepper is recalcitrant to transformation [44]. Similarly, the capacity to infect plants with geminiviruses via agroinoculation varies among species. Pepper is particularly difficult to infect via agroinoculation, especially with monopartite geminiviruses [45]. Unfortunately, this presents challenges for using agroinoculation to screen peppers for curly top resistance.

Together, our results indicate that MX-P24 is at the borderline of what constitutes a new curtovirus species vs. a highly divergent strain. The genome sequence is just below the threshold for a new species, and there are highly divergent regions of the genome (e.g., the IR). However, although MX-P24 induced a distinct symptom phenotype in tomato, the overall biological properties (host range and symptomatology) are similar to those of known BMCTV isolates. Taken together, our results indicate MX-P24 is a divergent strain of BMCTV, and the name Beet mild curly top virus-[Mexico: Zacatecas:Pepper24:2007] (BMCTV[MX:Zaca:P24:07]) is assigned.

Genetic diversity among begomovirus isolates has been reported for many species [7, 14, 15, 17, 22], and this reflects the high error rate associated with replication of these single-stranded DNA viruses. Although similar levels of variability have not been shown with curtovirus isolates, this may be due to the limited number and scope of the studies conducted. Indeed, evidence is now emerging that considerable genetic diversity exists among isolates of BCTV and BMCTV [12, 39, 41]. For example, a recent comprehensive analysis of curtovirus isolates associated with curly top of sugar beet in the western United States revealed a high level of genetic diversity among BCTV isolates, possibly reflecting ongoing speciation in an isolated region as well as diversity among BMCTV isolates [41]. Similarly, the identification of the highly divergent MX-P24 strain of BMCTV in the present study confirms that there can be a high level of genetic diversity among isolates of this curtovirus species, and this probably reflects evolution of a geographically isolated population in Mexico. In contrast, most BSCTV isolates characterized to date, including those from various crops from Old and New World locations, have been less variable, perhaps suggesting stabilizing selection within this species [11, 39, 41]. Together, these results indicate that high levels of diversity can exist among isolates of some curtovirus species. This also is consistent with the fact that the mechanism of single-stranded DNA replication is conserved among geminiviruses. Finally, this study is a good example of a situation where sequence analysis alone was not sufficient to provide a definitive determination of the classification and nomenclature of a geminivirus isolate, and the resolution of the issue required investigation of the biological properties of the virus.

Acknowledgments We thank Harris Moran Seed Company for providing samples and financial support.

Conflict of interest The authors declare that they have no conflict of interest.

Open Access This article is distributed under the terms of the Creative Commons Attribution Noncommercial License which permits any noncommercial use, distribution, and reproduction in any medium, provided the original author(s) and source are credited.

\section{References}

1. Baliji S, Black MC, French R, Stenger DC, Sunter G (2004) Spinach curly top virus: a newly described curtovirus species from southwest Texas with incongruent gene phylogenies. Phytopathology 94:772-779 
2. Baliji S, Sunter J, Sunter G (2007) Transcriptional analysis of complementary sense genes in Spinach curly top virus and functional role of $\mathrm{C} 2$ in pathogenesis. Mol Plant Microbe Interact 20:194-206

3. Bennett CW (1971) The curly top disease of sugarbeet and other plants. The American Phytopathological Society, St. Paul

4. Birch RG (1997) Plant transformation: problems and strategies for practical application. Ann Rev Plant Physiol Plant Mol Bio 48:297-326

5. Briddon RW, Watts J, Markham PG, Stanley J (1989) The coat protein of beet curly top virus is essential for infectivity. Virology 172:628-633

6. Briddon RW, Stenger DC, Bedford ID, Stanley J, Izadpanah K, Markham PG (1998) Comparison of a beet curly top virus isolate originating from the old world with those from the new world. Eur J Plant Pathol 104:77-84

7. Brown JK, Idris AM, Ostrow KM, Goldberg N, French R, Stenger DC (2005) Genetic and phenotypic variation of the pepper golden mosaic virus complex. Phytopathology 95:12171224

8. Chen L-F, Gilbertson RL (2008) Beet mild curly top virus. In: Rao GP, Paul Khurana SM, Lenardon S (eds) Characterization, diagnosis \& management of plant viruses. Studium Press LLC, Texas, pp 195-215

9. Chen L-F, Gilbertson RL (2009) Curtovirus-cucurbit interaction: acquisition host plays a role in leafhopper transmission in a hostdependent manner. Phytopathology 99:101-108

10. Chen L-F, Rojas M, Kon T, Gamby K, Xoconostle-Cazares B, Gilbertson RL (2009) A severe symptom phenotype in tomato in Mali is caused by a reassortant between a novel recombinant begomovirus (Tomato yellow leaf curl Mali virus) and a betasatellite. Mol Plant Pathol 10:415-430

11. Chen L-F, Brannigan K, Clark R, Gilbertson RL (2010) Characterization of curtoviruses associated with curly top disease of tomato in California and monitoring for these viruses in beet leafhoppers. Plant Dis 94:99-108

12. Creamer R, Hubble H, Lewis A (2005) Curtovirus infection of chile pepper in New Mexico. Plant Dis 89:480-486

13. Dellaporta SL, Wood J, Hicks JB (1983) A plant DNA minipreparation: version II. Plant Mol Biol Rep 1:19-21

14. Duffy S, Holmes EC (2008) Phylogenetic evidence for rapid rates of molecular evolution in the single-stranded DNA begomovirus tomato yellow leaf curl virus. J Virol 82:957-965

15. Duffy S, Holmes EC (2009) Validation of high rates of nucleotide substitution in geminiviruses: phylogenetic evidence from East African cassava mosaic viruses. J Gen Virol 90:1539-1547

16. Esau K (1976) Hyperplastic phloem and its plastids in spinach infected with the curly top virus. Ann Bot 40:637-644

17. Fauquet C, Briddon R, Brown J, Moriones E, Stanley J, Zerbini M, Zhou X (2008) Geminivirus strain demarcation and nomenclature. Arch Virol 153:783-821

18. Heydarnejad J, Abhari EH, Yazdi HRB, Massumi H (2007) Curly top of cultivated plants and weeds and report of a unique curtovirus from Iran. J Phytopathol 155:321-325

19. Hormuzdi SG, Bisaro DM (1993) Genetic analysis of beet curly top virus: evidence for three virion sense genes involved in movement and regulation of single- and double-stranded DNA levels. Virology 193:900-909

20. Hormuzdi SG, Bisaro DM (1995) Genetic analysis of Beet curly top virus: examination of the roles of L2 and L3 genes in viral pathogenesis. Virology 206:1044-1054

21. Hou Y-M, Paplomatas EJ, Gilbertson RL (1998) Host adaptation and replication properties of two bipartite geminiviruses and their pseudorecombinants. Mol Plant Microbe Interact 11:208-217

22. Jones DR (2003) Plant viruses transmitted by whiteflies. Euro J Plant Pathol 109:195-219
23. Klute KA, Nadler SA, Stenger DC (1996) Horseradish curly top virus is a distinct subgroup II geminivirus species with rep and C4 genes derived from a subgroup III ancestor. J Gen Virol 77:1369-1378

24. Lam N, Creamer R, Rascon J, Belfon R (2009) Characterization of a new curtovirus, pepper yellow dwarf virus, from chile pepper and distribution in weed hosts in New Mexico. Arch Virol 154:429-436

25. Latham JR, Saunders K, Pinner MS, Stanley J (1997) Induction of plant cell division by beet curly top virus gene C4. Plant J 11:1273-1283

26. Martin DP, Williamson C, Posada D (2005) RDP2: recombination detection and analysis from sequence alignments. Bioinformatics 21:260-262

27. Patel VP, Rojas MR, Paplomatas EJ, Gilbertson RL (1993) Cloning biologically active geminivirus DNA using PCR and overlapping primers. Nucleic Acids Res 21:1325-1326

28. Polston JE, Anderson P (1997) The emergence of whiteflytransmitted geminiviruses in tomato in the Western Hemisphere. Plant Dis 81:1358-1369

29. Soto MJ, Gilbertson RL (2003) Distribution and rate of movement of the curtovirus Beet mild curly top virus (family Geminiviridae) in the beet leafhopper. Phytopathology 93:478484

30. Soto MJ, Chen L-F, Seo Y-S, Gilbertson RL (2005) Identification of regions of the Beet mild curly top virus (family Geminiviridae) capsid protein involved in systemic infection, virion formation and leafhopper transmission. Virology 341:257-270

31. Stanley J, Markham PG, Callis RJ, Pinner MS (1986) The nucleotide sequence of an infectious clone of the geminivirus beet curly top virus. EMBO J 5:1761-1767

32. Stanley J, Latham JR, Pinner MS, Bedford I, Markham PG (1992) Mutational analysis of the monopartite geminivirus beet curly top virus. Virology 191:396-405

33. Stanley J, Bisaro DM, Briddon RW, Brown JK, Fauquet CM, Harrison BD, Rybicki EP, Stenger DC (2005) Family Geminiviridae. In: Fauquet CM, Mayo MA, Maniloff J, Desselberger U, Ball LA (eds) Virus taxonomy VIIIth report of the international committee on taxonomy of viruses. Elsevier/Academic Press, London, pp 301-326

34. Stanley J, Latham JR (1992) A symptom variant of beet curly top geminivirus produced by mutation of open reading frame $\mathrm{C} 4$. Virology 190:506-509

35. Stenger DC (1994) Complete nucleotide sequence of the hypervirulent $\mathrm{CFH}$ strain of beet curly top virus. Mol Plant Microbe Interact 7:154-157

36. Stenger DC (1995) Genotypic variability and the occurrence of less than genome-length viral DNA forms in a field population of beet curly top geminivirus. Phytopathology 85:1316-1322

37. Stenger DC (1998) Replication specificity elements of the Worland strain of Beet curly top virus are compatible with those of the $\mathrm{CFH}$ strain but not those of the Cal/Logan strain. Phytopathology 88:1174-1178

38. Stenger DC, Carbonaro D, Duffus JE (1990) Genomic characterization of phenotypic variants of beet curly top virus. J Gen Virol 71:2211-2215

39. Stenger DC, McMahon CL (1997) Genotypic diversity of beet curly top virus populations in the Western United States. Phytopathology 87:737-744

40. Stenger DC, Revington GN, Stevenson MC, Bisaro DM (1991) Replicational release of geminivirus genomes from tandemly repeated copies: evidence for rolling-circle replication of a plant viral DNA. Proc Natl Acad Sci USA 88:8029-8033

41. Strausbaugh CA, Wintermantel WM, Gillen AM, Eujayl IA (2008) Curly top survey in the Western United States. Phytopathology 98:1212-1217 
42. Velásquez-Valle R, Medina-Aguilar MM, Creamer R (2008) First report of Beet mild curly top virus infection of chile pepper in north-central Mexico. Plant Dis 92:650

43. Wang H, Buckley KJ, Yang X, Buchmann RC, Bisaro DM (2005) Adenosine kinase inhibition and suppression of RNA silencing by geminivirus AL2 and L2 proteins. J Virol 79:7410-7418

44. Wolf D, Matzevitch T, Steinitz B, Zelcer A (2001) Why is it difficult to obtain transgenic pepper plants? Acta Hortic 560: 229-233
45. Zhou YC, Noussourou M, Kon T, Rojas MR, Jiang H, Chen LF, Gamby K, Foster R, Gilbertson RL (2008) Evidence of local evolution of tomato-infecting begomovirus species in West Africa: characterization of tomato leaf curl Mali virus and tomato yellow leaf crumple virus from Mali. Arch Virol 153:693-706 